\title{
Hemşirelik Bölümü İntörn Öğrencilerin Merhamet Düzeyi ve Etkileyen Faktörler: Pilot Çalışma
}

\author{
$\underline{\text { Ahmet SEVEN }}^{1}$, Sebahat Gökçe DOĞAN $^{2}$, Ayșe KINIK $^{2}, \underline{\text { Kübra TORAMAN }}^{2}$, Güler DAȘIN $^{2}$, Gonca Gül SEVINEN ${ }^{2}, \underline{\text { Tuba }}$ \\ $\underline{\underline{\text { DOĞRU }^{2}}}$
}

\begin{abstract}
$\ddot{\mathbf{O z}}$
$\mathrm{Bu}$ çalışma, hemşirelik bölümü intörn öğrencilerinin merhamet düzeyleri ve etkileyen faktörlerini belirlemek amacıyla, çalışmaya katılmayı kabul eden 46 hemşirelik intörn öğrencisiyle tanımlayıcı ve kesitsel olarak yapıldı. Veriler sosyo-demografik özellikleri içeren soru formu ve Merhamet Ölçeği (MÖ) kullanılarak toplandı. Verilerin analizi bilgisayar ortamında; yüzdelik, ortalama, parametrik ve nonparametrik testler kullanılarak yapıldı. Yaş ortalaması 22,46 $\pm 2,08$ olan öğrencilerin \%80,4'ü kadın, \%58,7'si Süper/Anadolu Lisesi mezunu, \%80,4'ü orta gelirli, \%63'ü çocukluğunu ilde geçirmiş ve

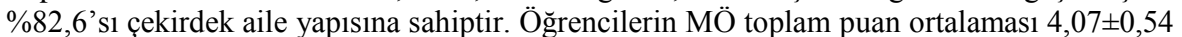

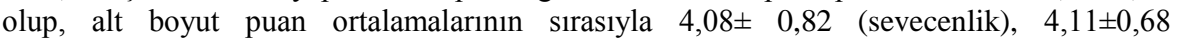

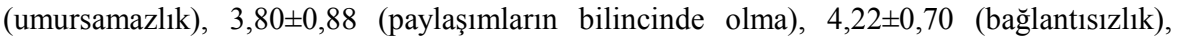
$3,96 \pm 0,77$ (bilinçli farkındalık) ve 4,26 0 ,76 (ilişki kesme) olduğu görüldü. Çalışmada, kadınların erkeklere göre MÖ paylaşımların bilincinde olma alt boyutundan daha yüksek puan aldıkları belirlendi. Çocukluğunu il merkezinde geçirenlerin ve arkadaşlarının sorunlarını çözmede aktif rol alanların merhamet düzeylerinin daha iyi olduğu saptandı $(\mathrm{p}<0,05)$. Çekirdek aile yapısına sahip olanların MÖ umursamazlık alt boyut puan ortalamalarının istatistiksel olarak daha yüksek olduğu görüldü $(p<0,05)$. "Anne eğitim düzeyi” değişkeni ile MÖ toplam, sevecenlik, umursamazlık ve ilişki kesme puan ortalamaları arasında anlamlı fark olduğu belirlendi $(p<0,05)$. Çalışmada hemşirelik intörn öğrencilerinin merhamet düzeylerinin yüksek olduğu; cinsiyet, aile yapısı, çocukluğunu geçirdiği yer, arkadaşlarının sorunlarını çözmede aktif rol alma ve anne eğitim durumlarının öğrencilerin merhamet düzeylerini etkilediği görüldü.
\end{abstract}

Gönderi Tarihi: 28.03.2019

Kabul Tarihi: 11.04.2019

Online Yayın Tarihi: 30.09.2019

DOI: $10.26453 /$ otjhs.546027

Anahtar kelimeler: Hemşirelik, intörn, merhamet, öğrenci

Compassion Levels of the Intern Students of Nursing and the Influencing Factors: Pilot Study

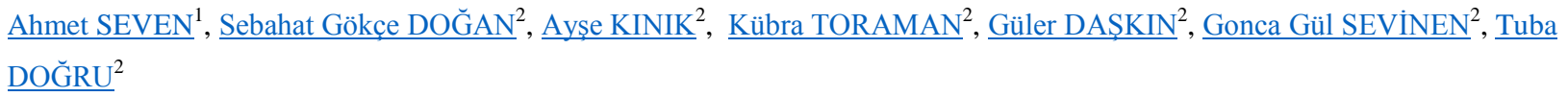

\begin{abstract}
This research aims to determine the compassion levels of intern students of nursing and the influencing factors. It is a descriptive population research, which has been conducted with the participation of 46 student nurse interns. The data have been collected through the questionnaire that covers socio-demographic features and Compassion Scale (CS). Of the students, whose average of age is $22.46 \pm 2.08,80.4 \%$ are female, $58.7 \%$ are Anatolian High School graduate, $80.4 \%$ have middle income, $63 \%$ were grown up in a city and $82.6 \%$ have nuclear family. The average of total CS scores of the students is $4.07 \pm 0.54$ and the subdimension average scores are respectively; $4.08 \pm 0.82$ (kindness), $4.11 \pm 0.68$ (indifference), $3.80 \pm 0.88$ (consciously sharing), $4.22 \pm 0.70$ (separation), $3.96 \pm 0.77$ (conscious awareness) and $4.26 \pm 0.76$ (disengagement). In the research, females have higher scores than males in sub-dimension of being aware of CS sharings. It has been detected that the ones who were grown up in city centers and who take an active role in solving their friends' problems have higher compassion levels $(\mathrm{p}<0.05)$. The ones who live in a nuclear family, statistically have higher average scores in sub-dimension of indifference $(p<0.05)$. A significant difference has been detected between the variable of "mother's level of education" and the average of total scores of CS kindness, indifference, and disengagement $(\mathrm{p}<0.05)$. It has been determined that intern students of nurse have high compassion levels; gender, family structure, place where they grew up, taking active role in solving their friends' problems and mothers' level of education are effective on the compassion levels of the students.
\end{abstract}

Sorumlu Yazar

Ahmet SEVEN

Sakarya University, School of Health Sciences, Sakarya, Turkey

Tel:+905055858404

e-Mail: aseven@sakarya.edu.tr

Key words: Nursing, intern, compassion, student

\footnotetext{
${ }^{1}$ Sakarya University Faculty of Health Sciences, Sakarya, Turkey

${ }^{2}$ Sakarya University Institude of Health Science, Sakarya, Turkey

https://orcid.org/0000-0002-2599-1918; https://orcid.org/0000-0002-5682-3925; https://orcid.org/0000-0002-5660-2137; https://orcid.org/0000-00022862-0792; https://orcid.org/0000-0002-1911-9883; https://orcid.org/0000-0002-4578-4924; https://orcid.org/0000-0001-5052-0141
}

\section{INTRODUCTION}


According to Turkish Language Society, the definition of compassion is; "feeling upset or merciful for a bad situation someone else or another living being encounters". "With another definition, compassion is the sense of awareness to eliminate the distress and pain of others, when witnessed. ${ }^{2}$

Compassion has several different definitions and it is likely to be often confused with different concepts like sympathy and empathy and sometimes used interchangeably. ${ }^{3}$ Especially the concepts of compassion and empathy are often being used interchangeably. ${ }^{4}$ While there is sharing of senses, putting oneself in someone else's shoes and understanding in the concept of empathy; compassion is about understanding the other and acting accordingly. ${ }^{5}$ Compassion is an innate sense for everybody. The senses of showing compassion for others, caring for them and helping them are available in everybody in different levels. ${ }^{6}$ Health professionals, especially nurses who are responsible for "preserving and developing the health and welfare of the individual, family and society and planning, organizing, practicing and evaluating the services for the recovery during illnesses", have the higher level of compassion and compassion is the foundation of the profession. Understanding the condition of the patients, relieving their pain and distress during patient care, are only possible by approaching the patient with compassion. ${ }^{7}$ Nurses can provide quality and professional service for patients by approaching them with the sense of compassion during care. ${ }^{8}$

During the treatment and patient care, the health professionals who spend the most time with patients are nurses and they are the first person patients/patient relatives consult in the case of a problem. Therefore, compassion the nurses' show for the patients is significantly effective on the treatment and caring process of the patients. ${ }^{9}$ In this regard, it has been aimed in this research to determine the levels of compassion and the effecting factors of the intern students of the nursing department, who will start their profession soon.

\section{MATERIAL AND METHODS}

The descriptive research was conducted between February-March 2018 with the authorization of the institution. Without sample choice, 46 student nurse interns who voluntarily accepted to participate in the research have set the sample group. Data have been collected through the questionnaire that covers the sociodemographic characteristics and five point likert type Compassion Scale (CS) which was developed by Pommier in 2010 and the Turkish validity and reliability of which was provided by Akdeniz and Deniz in 2016 and consists of 24 items and 6 sub-dimensions (kindness, indifference, consciously sharing, separation, conscious awareness and disengagement). ${ }^{3}$ While calculating the scores of the scale, the 
items in the sub-dimensions of indifference, separation and disengagement are being inverted. With the average of all the subdimension scores, the total scale score is being calculated. The more the score of the scale, the more the level of compassion is.

The data have been analyzed through SPSS (IBM SPSS Statistics 20) package software on computer. In the interpretation of the data, percentage, average, frequency tables and descriptive statistics have been used. In the comparison of two independent groups' evaluation values, Mann-Whitney $U$ test and in the comparison of independent three or more group's scale values, Kruskal Wallis H test have been used.

\section{RESULTS}

$80.4 \%$ of the students, whose average age is $22.46 \pm 2.08$, are female, $58.7 \%$ of them are Super/Anatolian High School graduate, 91.3\% of them are unemployed, $80.4 \%$ of them have middle income, $63 \%$ of them were grown up in a city and $82.6 \%$ of them have nuclear family. The education levels of their mothers $(41.3 \%)$ and fathers $(34.8 \%)$ are primary school. $32.6 \%$ of the students have taken care of one of their relatives for a long period of time. $60.9 \%$ of the participants have stated that the person who takes the most active role in the solution of the family problems is their mother, most of them are taking an active role in the solution of the problems among their friends (84.4\%) and $21.7 \%$ of them are carrying the burden of their family (Table 1).

The total CS score average of the students is 4.07 \pm 0.54 (Min-Max; 2.62-4.88), their subdimension score averages are respectively $4.08 \pm$ 0.82 (kindness), $4.11 \pm 0.68$ (indifference), $3.80 \pm 0.88$ (consciously sharing), $4.22 \pm 0.70$ (separation), 3.96 \pm 0.77 (conscious awareness) and 4.26 \pm 0.76 (disengagement) (Table 2).

The variables of age, high school of graduation, employment status, income status, father's level of education, taking care of a close relative for a long period of time, feeling of carrying the burden of the whole family and the person who takes the most active role in the solution of the family problems, have been detected not to effect the CS total and sub-dimension scores ( $>0.05)$ (Table 3). Between the variables of "the place where they grew up" and "taking an active role in solving the problems of their friends" and CS separation sub-dimension score averages, there have been detected statistically significant differences and the compassion levels of the ones who grew up in a city center and take an active role in solving the problems of their friends are found out to be higher $(p<0.05)$. It has been found out that there is a significant difference between the variable of "mother's level of education" and the total CS average scores of kindness, indifference and disengagement; the ones whose mothers' level 
of education is high school, have higher level of CS of indifference $(\mathrm{p}<0.05)(\underline{\text { Table } 3})$.

\section{DISCUSSION AND CONCLUSION}

Compassion is the primary professional value for health professionals, especially nurses. ${ }^{10} \mathrm{~A}$ quality nursery care for patients and increasing the quality of their lives is only possible with a compassionate approach to the patients. ${ }^{8}$ The level of compassion of the nurses has an important part in good care.

In a research of level of compassion, conducted with 227 nurses working in a university hospital, the compassion levels of the nurses found out to be mid-level. ${ }^{8}$ In the research conducted by Polat and Erdem, the level of compassion of health professionals, especially the nurses have been found out to be high. ${ }^{7}$ As a result of another research which was carried out with the participation of 494 nursing students, the CS averages have been found out to be (4.19 \pm 0.44$)$ high. $^{11}$ In the present research, the average score of compassion scale of the student nurse interns have been found out to be $4.07 \pm 0.54$. In line with the literature, in our research, the level of compassion of nursing students are high (Table 2).

In the research, it has been found out that gender affects the compassion levels of the students and females have higher compassion levels (in CS sharing sub-dimension) than males (Table 3). In this study, similar to the previous research, it has been detected that females have higher CS score averages than males. ${ }^{7}$ Similarly, in a research carried out by Çingöl et al, females have higher average of CS scores than males. ${ }^{11}$ We consider that, as most of the nurses are female and as females are more emotionally sensitive and compassionate than males, females have higher levels of compassion.

It has been found out that there is a statistically significant difference between the variables of "where they grew up" and "taking an active role in solving their friends' problems" and CS separation sub-dimension average scores; the ones who grew up in a city center and the ones who take an active role in solving their friends' problems have higher levels of compassion $(\mathrm{p}<0.05)$ (Table 3). It is possible to say that sensitivity of the students increase when they help someone and thus, as they take part in solving other people's problems, their level of compassion is high in our research.

Individuals who grew up in a crowded family, generally suffer from emotional deprivation in crowd and this might affect their level of compassion. ${ }^{12}$ In the research, a significant difference has been detected between the variable of "family structure" and CS indifference sub-dimension average scores $(p<0.05)$ and the ones who have a nuclear family, have higher score averages (Table 3). Related to the fact that individuals who have 
nuclear families get more attention, their level of compassion might be considered to be higher. In the research, it has been detected that the ones whose mothers have higher level of education have higher score averages of compassion scale scores (Table 3). In the research of Arkan et al, it has been determined that education affects the level of compassion. In the family environment where the basic education starts, it is possible to say, especially for the individuals who grow up by spending more time with their mothers that, the higher the mother's level of education, the higher the level of compassion. ${ }^{8}$

As a result, according to the findings of the research, the level of compassion of student nurse interns are high; age, family structure, where they grew up, taking an active role in solving their friends' problems and the education level of their mothers affect the compassion levels of the students. For more efficient results, it is suggested to carry out researches with more samples.

\section{REFERENCES}

1. Türk Dil Kurumu, merhamet, http://www.tdk.gov.tr/index.php?option =com_gts\&arama=gts\&guid=TDK.GTS. $\underline{\text { 5c8aadf68f0b99.63806650 }} \quad$ Erişim Tatihi: 27.03.2019.
2. Maben J, Cornwell J, Sweeney K. In praise of compassion. Journal Res Nurs. 2010;15(1);9-14.

3. Akdeniz S, Deniz ME. Merhamet ölçeğinin Türkçeye uyarlanması: geçerlik ve güvenirlik çalışması. The Journal of Happiness \& Well-Being. 2016;4(1):50-61.

4. Pommier EA. The compassion scale. Dissertation Abstracts International Section A: Humanities and Social Sciences. 2011;72,1174.

5. Way D, Tracy SJ. Conceptualizing compassion as recognizing, relating and (re) acting: A qualitative study of compassionate communication at hospice. Communication Monograph. 2012;79(3);292-315.

6. Gök A. Merhamet Etmenin Dayanılmaz Ağırlığı: Hemşirelerde Merhamet Yorgunluğu. Süleyman Demirel Üniversitesi İktisadi ve İdari Bilimler Fakültesi Dergisi. 2015;20 (2),299-313.

7. Polat FN, Erdem R. Merhamet Yorgunluğu Düzeyinin Çalışma Yaşam Kalitesi İle İlişkisi: Sağlık Profesyonelleri Örneği. Süleyman Demirel Üniversitesi Sosyal Bilimler Enstitüsü Dergisi. 2017;1(26): 291-312. 8. Arkan B, Y1lmaz D, Düzgün F. Determination of Compassion Levels of Nurses Working at a University Hospital. J Relig Health. 2019. Doi: 
https://doi.org/10.1007/s10943-019-

00786-X.

9. Kara D. Hemşirelerin Merhamet

Yorgunluklarının ve Öz Anlayışlarının İncelenmesi. Okan Üniversitesi, Sağlık

Bilimleri Enstitüsü, Hemşirelik Ana

Bilim Dalı Yüksek Lisans Tezi,

Danışman: Ebru Akgün Çıtak. 2018; İstanbul.

10. Bray L, O'Brien MR, Kirton J, Zubairu

K, Christiansen A.The role of professional education in developing compassionate practitioners: A mixed methods study exploring the perceptions of health professionals and preregistration students. Nurse Education Today. 2014;34:480-486. Doi: 10.1016/j.nedt.2013.06.017

11.Çingöl N, Çelebi E, Zengin S, Karakaş M. Bir Sağlık Yüksekokulu Hemşirelik Bölümü Öğrencilerinin Merhamet Düzeylerinin İncelenmesi. Klinik Psikiyatri Dergisi. 2018;21:61-67.

12. Aktaş AM. Aile İçi Şiddet Kadının ve Çocuğun Korunması. 1.Basım. Ankara: 2006, Elma Yayınevi. 
Table 1. Frequency and percent results of the demographic characteristics of the student.

\begin{tabular}{|c|c|c|}
\hline Characteristics & f & $\%$ \\
\hline \multicolumn{3}{|l|}{ Age } \\
\hline 22 years old and lower & 31 & 67.4 \\
\hline 23 years old and over & 15 & 32.6 \\
\hline \multicolumn{3}{|l|}{ Gender } \\
\hline Women & 37 & 80.4 \\
\hline Men & 9 & 19.6 \\
\hline \multicolumn{3}{|l|}{ Education Level } \\
\hline High school & 9 & 19.6 \\
\hline Anatolian High School & 27 & 58.7 \\
\hline Health Vocational High School & 10 & 21.7 \\
\hline \multicolumn{3}{|l|}{ Working Status } \\
\hline Yes & 4 & 8.7 \\
\hline No & 42 & 91.3 \\
\hline \multicolumn{3}{|l|}{ Income status } \\
\hline Bad & 5 & 10.9 \\
\hline Middle & 37 & 80.4 \\
\hline Good & 4 & 8.7 \\
\hline \multicolumn{3}{|l|}{ Where he spent his childhood } \\
\hline Village & 6 & 13.0 \\
\hline Town & 11 & 23.9 \\
\hline City & 29 & 63.0 \\
\hline \multicolumn{3}{|l|}{ Family structure } \\
\hline Nucleus & 38 & 82.6 \\
\hline Large & 7 & 15.2 \\
\hline Broken & 1 & 2.2 \\
\hline \multicolumn{3}{|l|}{ Mother education status } \\
\hline Illiterate & 3 & 6.5 \\
\hline Literate & 2 & 4.3 \\
\hline Primary school & 19 & 41.3 \\
\hline Middle School & 9 & 19.6 \\
\hline High school & 8 & 17.4 \\
\hline Undergraduate and above & 5 & 10.9 \\
\hline \multicolumn{3}{|l|}{ Father education status } \\
\hline Illiterate & 3 & 6.5 \\
\hline Literate & 2 & 4.3 \\
\hline Primary school & 16 & 34.8 \\
\hline Middle School & 7 & 15.2 \\
\hline High school & 13 & 28.3 \\
\hline Undergraduate and above & 5 & 10.9 \\
\hline \multicolumn{3}{|c|}{ Caring close relative for a long time } \\
\hline Yes & 15 & 32.6 \\
\hline No & 31 & 67.4 \\
\hline \multicolumn{3}{|c|}{ The most active person in solving family problems } \\
\hline Mother & 28 & 60.9 \\
\hline Father & 9 & 19.6 \\
\hline Brother & 2 & 4.3 \\
\hline Him/herself & 7 & 15.2 \\
\hline \multicolumn{3}{|c|}{ Active role of friends in solving problems } \\
\hline Yes & 39 & 84.8 \\
\hline No & 7 & 15.2 \\
\hline \multicolumn{3}{|c|}{ The situation of thinking that the family carries the burden } \\
\hline Yes & 10 & 21.7 \\
\hline No & 36 & 78.3 \\
\hline
\end{tabular}


Table 2. Distribution of nurses' overall scores of compassion score and subscale.

\begin{tabular}{llll}
\hline Compassion Score and subscale & M \pm SD & Median & $\begin{array}{l}\text { Min-Max } \\
\text { Point }\end{array}$ \\
\hline Total Compassion Score & $4.07 \pm 0.54$ & 4.12 & $2.62-4.88$ \\
Kindness & $4.08 \pm 0.82$ & 4.12 & $1.50-5$ \\
Indifference & $4.11 \pm 0.68$ & 4.25 & $2.25-5$ \\
Consciously sharing & $3.80 \pm 0.88$ & 3.87 & $2.50-5$ \\
Separation & $4.22 \pm 0.70$ & 4.50 & $2.25-5$ \\
Conscious awareness & $3.96 \pm 0.77$ & 4.00 & $2-5$ \\
Disengagement & $4.26 \pm 0.76$ & 4.50 & $1.50-5$ \\
\hline
\end{tabular}


Table 3. Overall scores of compassion score and subscale according to socio-demographic characteristics.

\begin{tabular}{|c|c|c|c|c|c|c|c|}
\hline Characteristics & $\begin{array}{l}\text { Total } \\
\text { Compassion } \\
\text { Score }\end{array}$ & Kindness & Indifference & $\begin{array}{l}\text { Consciously } \\
\text { sharing }\end{array}$ & Separation & $\begin{array}{l}\text { Conscious } \\
\text { awareness }\end{array}$ & Disengagement \\
\hline $\begin{array}{l}\text { Age } \\
22 \text { years old and } \\
\text { lower } \\
23 \text { years old and } \\
\text { over }\end{array}$ & $\begin{array}{c}22.60 \\
25.37 \\
z=--0.657 \\
p=0.511\end{array}$ & $\begin{array}{c}22.69 \\
25.17 \\
z=-0.591 \\
p=0.554\end{array}$ & $\begin{array}{c}22.31 \\
25.97 \\
z=-0.875 \\
p=0.381\end{array}$ & $\begin{array}{c}24.27 \\
21.90 \\
z=-0.566 \\
p=0.571\end{array}$ & $\begin{array}{c}23.35 \\
23.80 \\
z=-0.107 \\
p=0.915\end{array}$ & $\begin{array}{c}22.79 \\
24.97 \\
z=-0.519 \\
p=0.604\end{array}$ & $\begin{array}{c}22.56 \\
25.43 \\
z=-0.691 \\
p=0.490\end{array}$ \\
\hline $\begin{array}{l}\text { Gender } \\
\text { Women } \\
\text { Men }\end{array}$ & $\begin{array}{c}25.35 \\
15.89 \\
\mathrm{z}=--1.899 \\
\mathrm{p}=0.058\end{array}$ & $\begin{array}{c}24.58 \\
19.06 \\
z=--1.118 \\
p=0.264\end{array}$ & $\begin{array}{c}23.66 \\
22.83 \\
z=--0.168 \\
p=0.867\end{array}$ & $\begin{array}{c}25.45 \\
15.50 \\
z=--2.007 \\
\mathbf{p}=\mathbf{0 . 0 4 5}\end{array}$ & $\begin{array}{c}25.38 \\
15.78 \\
z=-1.947 \\
p=0.051\end{array}$ & $\begin{array}{c}24.91 \\
17.72 \\
z=-1.449 \\
p=0.147\end{array}$ & $\begin{array}{c}24.50 \\
19.39 \\
z=--1.899 \\
p=0.058\end{array}$ \\
\hline $\begin{array}{l}\text { Working Status } \\
\text { Yes } \\
\text { No }\end{array}$ & $\begin{array}{c}16.38 \\
24.18 \\
z=-1.112 \\
p=0.266\end{array}$ & $\begin{array}{c}17.38 \\
24.08 \\
z=-0.964 \\
p=0.335\end{array}$ & $\begin{array}{c}15.38 \\
24.27 \\
z=-1.279 \\
p=0.201\end{array}$ & $\begin{array}{c}15.75 \\
24.24 \\
z=-1.217 \\
p=0.224\end{array}$ & $\begin{array}{c}19.62 \\
23.87 \\
z=-0.611 \\
p=0.541\end{array}$ & $\begin{array}{c}23.25 \\
23.52 \\
z=-0.039 \\
p=0.969\end{array}$ & $\begin{array}{c}14.50 \\
24.36 \\
z=-1.427 \\
p=0.154\end{array}$ \\
\hline $\begin{array}{l}\text { Caring close } \\
\text { relative for a } \\
\text { long time } \\
\text { Yes } \\
\text { No }\end{array}$ & $\begin{array}{c}23.73 \\
23.39 \\
z=-0.082 \\
p=0.935\end{array}$ & $\begin{array}{c}24.53 \\
23.00 \\
z=-0.366 \\
p=0.714\end{array}$ & $\begin{array}{c}24.30 \\
23.11 \\
z=-0.284 \\
p=0.776\end{array}$ & $\begin{array}{c}22.37 \\
24.05 \\
z=-0.401 \\
p=0.688\end{array}$ & $\begin{array}{c}20.07 \\
25.16 \\
\mathrm{z}=-1.221 \\
\mathrm{p}=0.222\end{array}$ & $\begin{array}{c}26.10 \\
22.24 \\
z=-0.920 \\
p=0.358\end{array}$ & $\begin{array}{c}23.67 \\
23.42 \\
z=-0.060 \\
p=0.952\end{array}$ \\
\hline $\begin{array}{l}\text { Active role of } \\
\text { friends in solving } \\
\text { problems } \\
\text { Yes } \\
\text { No }\end{array}$ & $\begin{array}{c}25.19 \\
14.07 \\
\mathbf{z}=-\mathbf{2 . 0 2 1} \\
\mathbf{p}=\mathbf{0 . 0 4 3}\end{array}$ & $\begin{array}{c}25.12 \\
14.50 \\
z=-1.944 \\
p=0.052\end{array}$ & $\begin{array}{c}24.83 \\
16.07 \\
z=-1.606 \\
p=0.108\end{array}$ & $\begin{array}{c}23.27 \\
24.79 \\
z=-0.277 \\
p=0.782\end{array}$ & $\begin{array}{c}25.15 \\
14.29 \\
\mathbf{z}=\mathbf{- 1 . 9 9 6} \\
\mathbf{p}=\mathbf{0 . 0 4 6}\end{array}$ & $\begin{array}{c}24.55 \\
17.64 \\
z=-1.262 \\
p=0.207\end{array}$ & $\begin{array}{c}25.29 \\
13.50 \\
\mathbf{z}=-\mathbf{2 . 1 7 7} \\
\mathbf{p}=\mathbf{0 . 0 2 9}\end{array}$ \\
\hline $\begin{array}{l}\text { The situation of } \\
\text { thinking that the } \\
\text { family carries } \\
\text { the burden } \\
\text { Yes } \\
\text { No }\end{array}$ & $\begin{array}{c}25,10 \\
23.06 \\
z=-0.427 \\
p=0.670\end{array}$ & $\begin{array}{c}23.30 \\
23.56 \\
z=-1.155 \\
p=0.248\end{array}$ & $\begin{array}{c}24.90 \\
23.11 \\
z=-1.546 \\
p=0.122\end{array}$ & $\begin{array}{c}23.40 \\
23.53 \\
z=-0.121 \\
p=0.904\end{array}$ & $\begin{array}{c}23.95 \\
23.38 \\
\mathrm{z}=-0.027 \\
\mathrm{p}=0.979\end{array}$ & $\begin{array}{c}17.75 \\
25.10 \\
z=-0.375 \\
p=0.707\end{array}$ & $\begin{array}{c}27.80 \\
22.31 \\
z=-0.054 \\
p=0.957\end{array}$ \\
\hline $\begin{array}{l}\text { Education Level } \\
\text { High school } \\
\text { Anatolian High } \\
\text { School } \\
\text { Health vocational } \\
\text { high School }\end{array}$ & $\begin{array}{c}23.50 \\
24.43 \\
21.00 \\
x^{2}=0.476 \\
p=0.788\end{array}$ & $\begin{aligned} 21.55 \\
24.50 \\
24.48 \\
\mathrm{x}^{2}=0.910 \\
\mathrm{p}=0.634\end{aligned}$ & $\begin{array}{c}23.67 \\
24.17 \\
19.95 \\
\mathrm{x}^{2}=0.284 \\
\mathrm{p}=0.867\end{array}$ & $\begin{array}{c}25.17 \\
24.11 \\
20.35 \\
\mathrm{x}^{2}=0.755 \\
\mathrm{p}=0.685\end{array}$ & $\begin{aligned} 23.67 \\
24.67 \\
20.20 \\
\mathrm{x}^{2}=0.829 \\
\mathrm{p}=0.661\end{aligned}$ & $\begin{array}{c}21.78 \\
24.15 \\
23.30 \\
\mathrm{x}^{2}=0.216 \\
\mathrm{p}=0.898\end{array}$ & $\begin{array}{c}24.33 \\
24.50 \\
20.05 \\
\mathrm{x}^{2}=0.874 \\
\mathrm{p}=0.646\end{array}$ \\
\hline $\begin{array}{l}\text { Income status } \\
\text { Bad } \\
\text { Middle } \\
\text { Good }\end{array}$ & $\begin{array}{c}19.20 \\
24.41 \\
20.50 \\
\mathrm{x}^{2}=0.883 \\
\mathrm{p}=0.643\end{array}$ & $\begin{array}{c}19.80 \\
24.31 \\
20.62 \\
\mathrm{x}^{2}=0.711 \\
\mathrm{p}=0.701\end{array}$ & $\begin{array}{c}13.50 \\
24.80 \\
24.00 \\
\mathrm{x}^{2}=3.187 \\
\mathrm{p}=0.203\end{array}$ & $\begin{array}{c}21.60 \\
25.03 \\
11.75 \\
\mathrm{x}^{2}=3.693 \\
\mathrm{p}=0.158\end{array}$ & $\begin{array}{c}18.00 \\
23.81 \\
27.50 \\
\mathrm{x}^{2}=1.244 \\
\mathrm{p}=0.537\end{array}$ & $\begin{array}{c}26.90 \\
23.59 \\
18.38 \\
\mathrm{x}^{2}=0.917 \\
\mathrm{p}=0.632\end{array}$ & $\begin{array}{c}18.50 \\
24.19 \\
23.38 \\
\mathrm{x}^{2}=0.819 \\
\mathrm{p}=0.664\end{array}$ \\
\hline $\begin{array}{l}\text { Where he spent his } \\
\text { childhood } \\
\text { Village } \\
\text { Town } \\
\text { City }\end{array}$ & $\begin{array}{c}14.00 \\
21.68 \\
26.16 \\
\mathrm{x}^{2}=4.352 \\
\mathrm{p}=0.113\end{array}$ & $\begin{array}{c}16.42 \\
26.45 \\
23.84 \\
x^{2}=2.263 \\
p=0.322\end{array}$ & $\begin{array}{c}20.83 \\
20.36 \\
25.24 \\
\mathrm{x}^{2}=1.351 \\
\mathrm{p}=0.509\end{array}$ & $\begin{array}{c}18.25 \\
19.55 \\
26.09 \\
\mathrm{x}^{2}=2.989 \\
\mathrm{p}=0.224\end{array}$ & $\begin{array}{c}11.50 \\
22.23 \\
26.47 \\
\mathbf{x}^{\mathbf{2}}=\mathbf{6 . 4 6 1} \\
\mathbf{p}=\mathbf{0 . 0 4 0}\end{array}$ & $\begin{array}{c}18.92 \\
22.50 \\
24.83 \\
\mathrm{x}^{2}=1.058 \\
\mathrm{p}=0.589\end{array}$ & $\begin{array}{c}14.75 \\
23.77 \\
25.21 \\
x^{2}=3.127 \\
p=0.209\end{array}$ \\
\hline
\end{tabular}




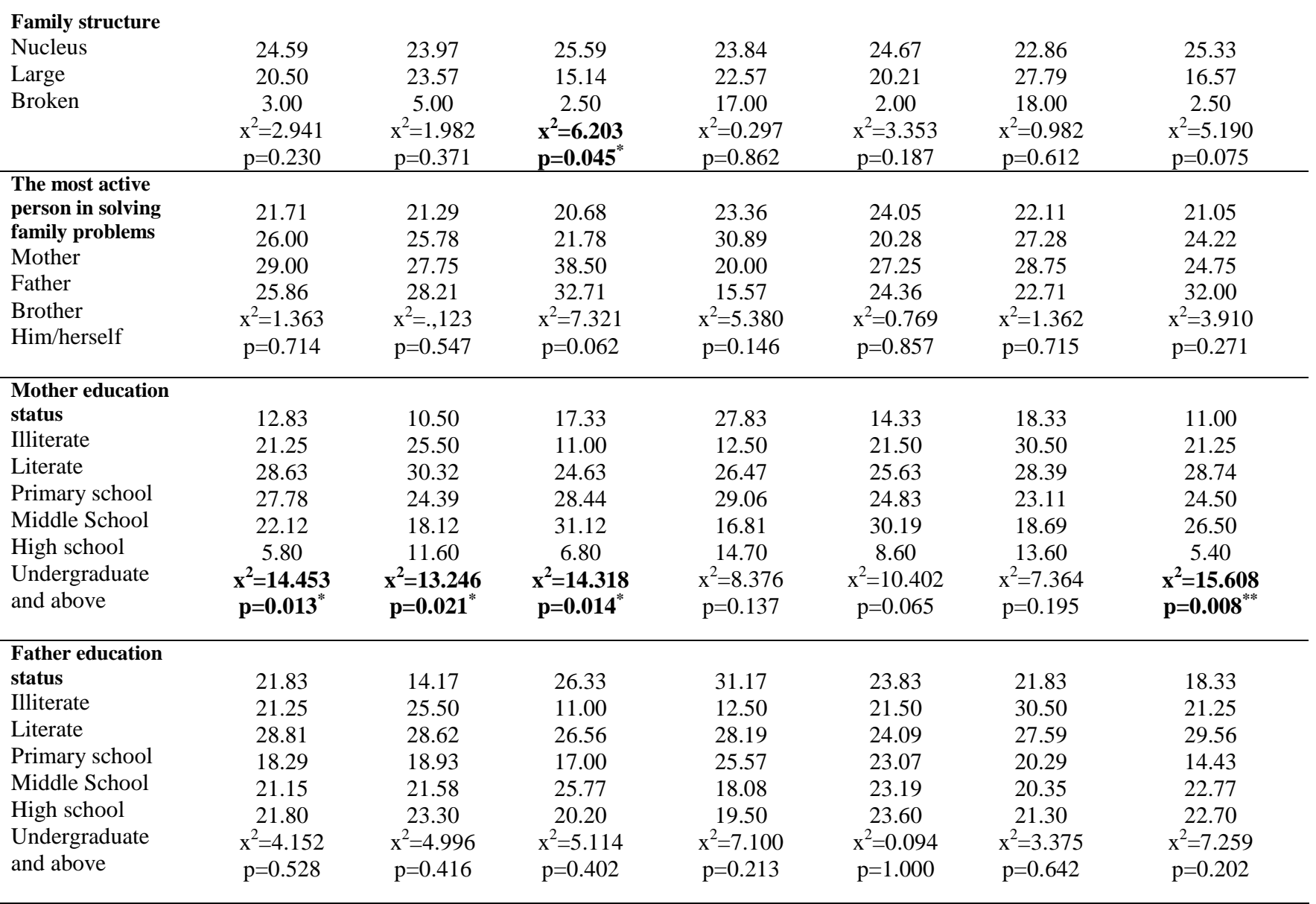

z: Man Whitney U, *p<.05, $\mathrm{x}^{2}$ :Kruskall Wallis H test *p<.05, ** $\mathrm{p}<.01$ 